DOI: 10.20472/IAC.2018.044.006

SAYAN BANERJEE

Chandragupt Institute of Management Patna , India

\title{
INDUSTRIAL PRODUCTS AND SHIFT IN VALUE CHAIN - PERSPECTIVES BEHIND INNOVATION POLICY
}

\begin{abstract}
:
To get to a final industrial product the consequent value chain always involves changes from left the basic raw materials to the right- the final product .Not getting into the technological nitty gritty this paper is an humble attempt to understand this shift in value chain of an industrial product with aspects like export portfolio and national innovation systems of different countries. This paper has tried to build up the narrative of ( Ling $\&$ Tang ,2009) by revisiting their perspectives with aspects like innovation systems and export portfolio. On this basis an attempt has been made to conceptualise a pertinent innovation policy of different category of countries based on economic and other factors. The aim of this paper is to help in the process of understanding of optimum innovation policies through various assorted aspects which can be interlinked with various innovation activities of a country.
\end{abstract}

\section{Keywords:}

National Innovation System, theory of competitive advantage,theory of comparative advantage

JEL Classification: M16 